\title{
Zooplankton communities in Mediterranean temporary lakes: the case of saline lakes in Cyprus
}

\author{
Aikaterini Karagianni ${ }^{1}$, Georgia Stamou ${ }^{1}$, Matina Katsiapi ${ }^{2}$, Polina Polykarpou ${ }^{3}$, Gerald Dörflinger ${ }^{3}$ and \\ Evangelia Michaloudi ${ }^{1, *}$ \\ ${ }^{1}$ Department of Zoology, School of Biology, Aristotle University of Thessaloniki, Thessaloniki, Greece \\ 2 Department of Botany, School of Biology, Aristotle University of Thessaloniki, Thessaloniki, Greece \\ ${ }^{3}$ Water Development Department, 100-110 Kennenty Avenue, CY-1047 Pallouriotissa, 1646 Nicosia, Cyprus
}

Received: 1 November 2017; Accepted: 19 February 2018

\begin{abstract}
Temporary saline lakes are diverse ecosystems mostly located in arid areas. In the Mediterranean region they are among the most remarkable, but also the most threatened habitats; thus, effective management and conservation plans need to consider their special hydrological and ecological features and requirements. They are mainly fishless systems and so zooplankton is the driver of the trophic cascade. Our aim was to determine zooplankton communities' composition and biomass in seven temporary saline lakes of Cyprus and investigate their relation with environmental variables. Salinity ranged between $<2$ and $300 \mathrm{ppt}$ and was a key factor shaping zooplankton community. In hyposaline conditions zooplankton communities exhibited higher species diversity than in meso- and hypersaline conditions. Hyposaline lakes were dominated by Arctodiaptomus salinus (Daday, 1885), Daphnia magna Straus, 1820 and Moina brachiata (Jurine, 1820) in terms of biomass, while meso- and hypersaline lakes by anostracans Artemia salina (Linnaeus, 1758) and Phallocryptus spinosus (Milne-Edwards, 1840) or M. brachiata and D. magna highlighting competition as another factor shaping the zooplankton community. We conclude that zooplankton reflects environmental pressures, such as salinity fluctuations which are closely related to water level fluctuations, in the mostly fishless Mediterranean temporary saline lakes. Moreover, salinity fluctuations should be considered a key factor for typological considerations in quality assessments, restoration and management plans in temporary saline systems since it can reflect the hydrological variations on the communities across different years and seasons by salinity gradient even for the same water body.
\end{abstract}

Keywords: Zooplankton / Mediterranean region / temporary shallow lakes / saline lakes / diversity

\section{Introduction}

Saline lakes range from small temporary ponds to large deep waterbodies like the Caspian Sea (Eugster and Hardie, 1978). They are diverse ecosystems with important aesthetic, cultural, economic, recreational, scientific, conservation and ecological values (Williams, 1993; Williams, 1998); moreover, they play an important role in the landscape including being biodiversity refugia (O'Connell et al., 2006). Saline lakes are characterized by salinity levels higher than $3 \mathrm{ppt}$ and have no direct connection to the marine environment (Williams, 2002). Although geographically widespread, they are located mostly in arid areas, where they tend to be more abundant than freshwater systems (Hammer, 1986). In the Mediterranean region, these ecosystems naturally fluctuate in both size and salinity because of natural changes in wet and drought cycles

*Corresponding author: tholi@bio.auth.gr
(Jarecki and Walkey, 2006); they are usually characterized by a flooding period in winter and spring, and a dry season in summer and autumn (Zacharias et al., 2007). Yet, some of them may hold water for more than one year while others may remain dry for more than one season, depending on the amount of rainfall (Zacharias et al., 2007). Consequently, ecosystem function and ecological equilibrium are mainly regulated by water level fluctuations and salinity which can differ each year according to each climatic pattern (Williams, 2002). Changes in water balance and, consequently, changes in physical and chemical characteristics of the water column are reflected in existing communities (Kirono et al., 2012). The composition of the biota living in such habitats is remarkably distinguishable from other aquatic habitats (Williams, 2002) since these organisms have developed unique physiological and biochemical mechanisms for living in a hyperosmotic medium. Mostly, it comprises halotolerant species of freshwater habitats, but with increasing salinity these disappear and are replaced with species found only in saline lakes (Hammer, 1986). 
Several studies have been conducted regarding zooplankton in saline habitats (e.g., Davis, 2000; Brucet et al., 2010) and most of them have identified the strong effect of salinity on the distribution of zooplankton, while few of them also identified influence of other environmental factors too (Boronat et al., 2001; Vieira and Bio, 2011). Zooplankton species possess several life history traits (diapause, encystment, production of resting eggs, short life-cycles, high reproduction rates, rapid development) that allow them to adapt in highly variable environments, in conditions of osmotic stress and desiccation (Williams, 1985; Hairston, 1996; Brock et al., 2003). Among zooplankton species, crustaceans, such as Artemiidae which are able to survive in stressful conditions like extreme salinity, high or low temperature, and anoxia (Torrentera and Dodson, 2004), and certain species of copepods, which are able to respond to environmental changes, dominate in saline systems (e.g., Alonso, 1990; Torrentera and Dodson, 2004; Khemakhem et al., 2010). Thus, they can be considered as good indicators of saline conditions (Marques et al., 2011). Although zooplankton community is a key component of the aquatic food webs (e.g., Moss et al., 2003; Jeppesen et al., 2011; Haberman and Haldna, 2014), it is not included as a biological quality element in the water framework directive 2000/60/EE (WFD) (European Commission, 2000). Nonetheless, a number of zooplankton multimetric indices have been developed for the assessment of ecological water quality in European lakes (e.g., Moss et al., 2003; Boix et al., 2005) and for the selection of priority conservation areas in the Mediterranean region (Gilbert et al., 2014).

Temporary saline lakes are among the most remarkable, but also the most threatened habitats in the Mediterranean region (Zacharias and Zamparas, 2010). Intensive catchment activities (e.g., pumping of surface/groundwater, dredging, inflow diversion) and human-induced climate change are major drivers of impact (Stenger-Kovács et al., 2014). The European Union has included Mediterranean temporary saline lakes in its conservation plans (Habitats Directive, e.g., Natura codes 1150, 3140 and 92D0, 92/43/EEC) (Council of the European Commission, 1992). Still, based on the criteria of the Habitats Directive (i.e. vegetation), not all the saline water bodies can be identified as "Habitats". Moreover, such temporary aquatic habitats, same as all surface waters, should be protected, monitored and restored (if needed) following the guidelines of the WFD (European Commission, 2000).

In the Mediterranean island of Cyprus, saline lakes constitute the only natural lake asset of the island since all other lentic waters of significant size are freshwater reservoirs. Although for the majority of these lakes, physical and chemical data and available, studies on their biological component are rather limited. In particular, the study of zooplankton communities is limited to species-based approaches in both ecological and molecular aspects (e.g., Mura and Hadjstephanou, 1987; Ketmaier et al., 2008; Munoz et al., 2008; Tziortzis et al., 2014). New insights on the biota of such saline lakes, which are subjected to active conservation (e.g., RAMSAR, NATURA 2000, etc.) will provide valuable ecological knowledge to be considered in their ecological and conservation management plans.

Thus, this is the first whole-community approached study on the zooplankton community of the saline lakes of Cyprus.

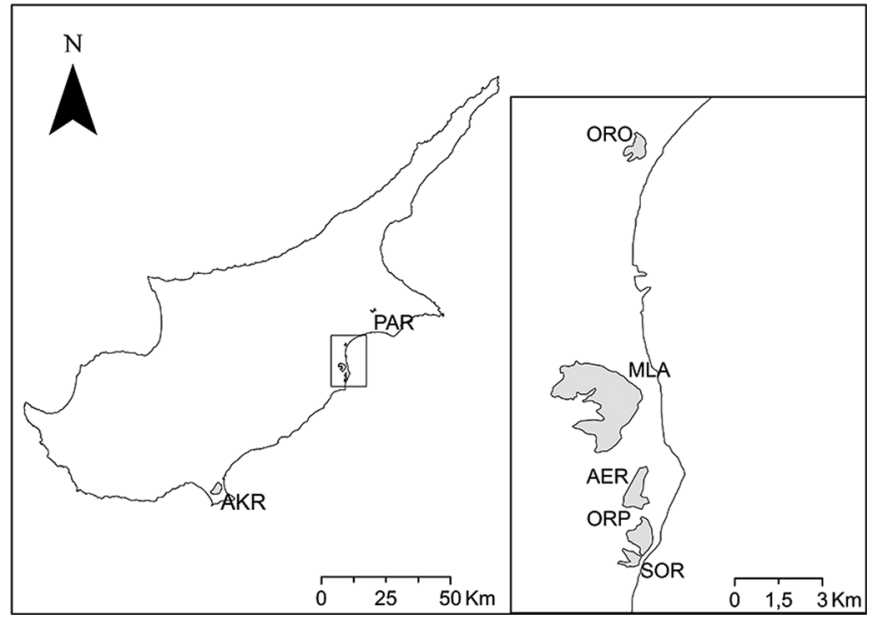

Fig. 1. Map of Cyprus showing the locations of the seven lakes included in the study. Abbreviations Megali Larnaka Lake (MLA), Airport Salt Lake (AER), Soros Salt Lake (SOR), Orphani Salt Lake (ORP), Akrotiri Salt Lake (AKR), Lake Paralimni (PAR), Lake Oroklini (ORO).

The objective of the present work was to study the zooplankton communities in seven temporary saline lakes of Cyprus, analyzing the taxonomic composition and biomass of the populations, with the aim of contributing to the knowledge of zooplankton communities across a salinity gradient in the Mediterranean area. More specifically, our aim was to:

- explore the diversity of the encountered zooplankton community;

- determine the principal environmental parameters that affect zooplankton community;

- provide valuable ecological knowledge to be considered in ecological and conservation management plans.

\section{Materials \& methods}

\subsection{Study site}

Samples were collected from seven lakes in Cyprus (Fig. 1); Megali Larnaka Lake (MLA), Airport Salt Lake (AER), Soros Salt Lake (SOR), Orphani Salt Lake (ORP), Akrotiri Salt Lake (AKR), Lake Paralimni (PAR) and Lake Oroklini (ORO). All of them are temporary salt lakes, located in an arid to semi-arid areas at elevations below $200 \mathrm{~m}$ a.s.l. They are mainly fishless or the presence of fish populations is restricted to the peak of wet periods. They are characterized by shallowness (depth from 0.05 to $1 \mathrm{~m}$ ), small surface area (0.4$\left.9.4 \mathrm{Km}^{2}\right)$ and varying salinity levels $(<2-300 \mathrm{ppt})$. Although they are protected sites, they are susceptible to eutrophication since they are subjected to important anthropogenic pressures (agricultural and artificial land coverage in the basin $>40 \%$, (Dörflinger et al., unpublished data) (LAWA, 2003). Moreover, elevated values of TP (maximum values: $83-260 \mu \mathrm{g} / \mathrm{L}$ ) supporting eutrophic conditions (Smith, 2003) were recorded in all the lakes during 2014-2016 (Water Development Department of Cyprus, unpublished data).

Megali Larnaka Lake, Airport Sat Lake, Orphani Salt Lake and Soros Salt Lake, which are separated by natural and 
artificial embankments, constitute the Larnaka Salt Lakes complex. All of them except Soros Salt Lake are interconnected. Akrotiri Salt Lake is surrounded by saltwater and freshwater marshes. Both Larnaka Salt Lakes complex and Akrotiri Salt Lake are coastal lakes without natural outflow. Lake Paralimni is surrounded by an urbanized area and consists of a main lake body with outflow occurring through a channel that was, at least in its present state, constructed in the XX century. Lake Oroklini is a marshy coastal lake that, due to drainage works during the XX century, consists at present of a main lake body, which is impounded by an artificial embankment and an overflow weir, and of several drainage channels and small ponds downstream of the overflow weir.

\subsection{Field work}

Samplings were conducted during the period of 20142016, provided that water was present. The information concerning frequency and stations of samplings are given in Table 1. During each sampling physical and chemical parameters were measured and phytoplankton and zooplankton samples were collected. Water depth, water temperature, $\mathrm{pH}$, conductivity and salinity were measured in situ using an Idronaut CTD 316 Plus. Due to the shallowness of the studied lakes, surface phytoplankton samples were collected using a $1 \mathrm{~L}$ plastic bucket; each sample was further separated in two $500 \mathrm{~mL}$ plastic flasks, one kept live for qualitative analysis and one preserved with Lugol for quantitative analysis. For zooplankton analysis, at least $30 \mathrm{~L}$ of water were filtered each time through mesh size of $50 \mu \mathrm{m}$ and were preserved in $4 \%$ formalin (final concentration).

\subsection{Phytoplankton analysis}

Live and Lugol preserved samples were examined under a light inverted microscope (Carl Zeiss Axio Observer.A1), and species were identified using appropriate taxonomic keys (Huber-Pestalozzi, 1938; Tikkanen, 1986). Phytoplankton counts were performed using the sedimentation method of Utermöhl (1958). For biovolume estimation, the size of 30 individuals (cells, filaments or colonies) of each species was measured using tools of a digital microscope camera (Nikon DS-L1). Mean cell or filament volume estimates were calculated using appropriate geometric formulae (Hillebrand et al., 1999). For the conversion of biovolume to biomass values, water density (i.e. $1 \mathrm{~g} / \mathrm{cm}^{3}$ ) was used (Rott, 1981)

\subsection{Zooplankton analysis}

Laboratory analysis included species identification and abundance and biomass estimates. For the species identification, at least 400 individuals per sample were examined under a light microscope. Zooplankton taxa were identified to the lowest possible taxonomic level using appropriate taxonomic keys [(for rotifers: Koste (1978), Nogrady et al. (1995), Segers (1995), Nogrady and Segers (2002); for cladocerans: Amoros (1984), Alonso (1996), Benzie (2005); for copepods: Dussart (1967), Kiefer (1971), Reddy (1994), Einsle (1996), Dussart and Defaye (2001); for anostracans: Alonso (1996), Brtek and Mura (2000)]; in most cases all the way down to species level, whereas harpacticoids (Copepoda, Harpacticoida) and ostracods (Ostracoda, Podocopa) were only identified to order level. For abundance analysis, for each sample (total volume of 50 or $100 \mathrm{~mL}$ ), five counts of $1 \mathrm{~mL}$ subsamples were made on a Sedgwick-Rafter cell, using a light microscope (Leitz Laborlux S). In the cases where the subsample count was less than 60 individuals, the whole sample was counted. Biomass was calculated as approximations using mean individual dry weight values (Dumont et al., 1975; Bottrell et al., 1976; Maier, 1994; Michaloudi, 2005; Michaloudi unpublished; González et al., 2008; Anh et al., 2009; Azevedo et al., 2012; Svetlichny et al., 2012). Species and taxonomical groups comprising more than $20 \%$ of the total zooplankton abundance and biomass were considered to be dominant (Haberman, 1976a and b).

\subsection{Data analysis}

For the data analysis all lakes were classified into three categories according to their salinity values $(0-10,34-50$ and 50-300 ppt) according to salinity spectra suggested by Hammer (1986). Moreover, for the better understanding of communities' biodiversity patterns the latter category (50$300 \mathrm{ppt}$ ) was divided further in two subcategories $50-70 \mathrm{ppt}$ and $>70 \mathrm{ppt}$.

In order to identify the similarity of the zooplankton communities among each sample, hierarchical cluster analysis based on the Bray-Curtis similarity index (Bray and Curtis, 1957) was performed on the zooplankton taxa's biomass matrix. Biomass data were transformed into $\log (x+1)$ in order to reduce bias due to highly abundant groups. CLUSTER was run using group-average linking. The Similarity profile (SIMPROF) permutation test option (default settings of 999 permutations and significance level $=0.05$ ) was applied to indicate significant groups in the resulting dendrogram. The similarity analysis routines, analysis of similarity (ANOSIM) and similarity percentage analysis (SIMPER) were used to test the significance levels and sources of variance between the various zooplankton assemblages associated with the different groupings identified in the hierarchical cluster analysis. The above analyses were conducted with the Plymouth Routine in Multivariate Ecological Research (PRIMER) v.6 software package (Clarke and Gorley, 2006).

Community diversity and evenness were determined according to Shannon (1948) and Pielou (1969), respectively. Differences between the means of the total number of zooplankton taxa (S), Shannon diversity index $\left(\mathrm{H}^{\prime}\right)$ and Pielou's Evenness $(\mathrm{J})$ in each salinity category were tested by analysis of variance (One-way ANOVA) and a Fisher's least significant difference (LSD) procedure. Weight cases were used to reduce bias due to there being different number of samplings in each group. Analyses were performed using IBM SPSS Statistics 22.

Direct ordination analyses were used to assess significant relationships between biological and environmental data. Samplings with missing actual environmental data were excluded from the analysis. All variables, except $\mathrm{pH}$, were log $(x+1)$ transformed, because of the occurrence of zero values. Previously, a detrended correspondence analysis (DCA) was performed and, as biological data showed a bell-shaped response with respect to environmental gradients, a canonical 
A. Karagianni et al.: Ann. Limnol. - Int. J. Lim. 2018, 54, 14

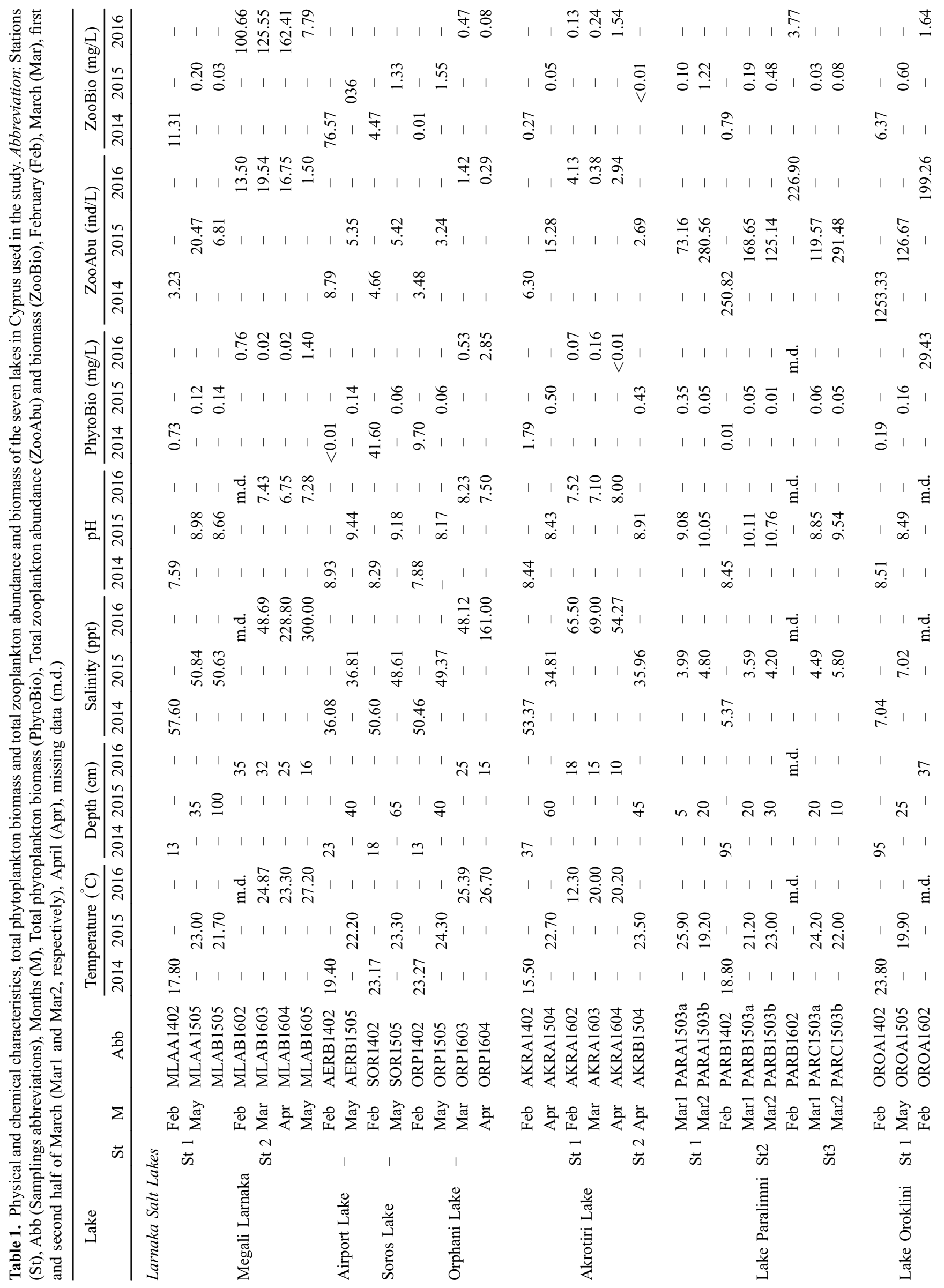




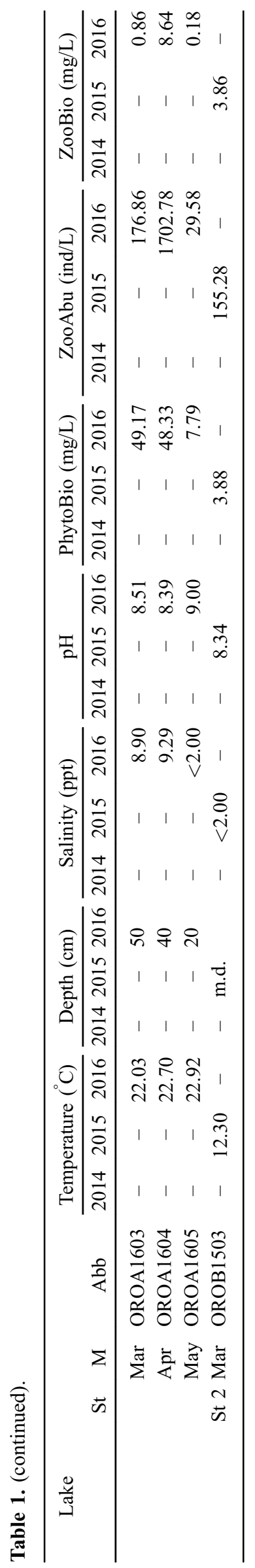

correspondence analysis (CCA) was applied. All environmental parameters with an inflation factor $<20$ were included in the analysis as explanatory variables (Ter Braak and Verdonschot, 1995); the biomass of each zooplankton taxon was included as response variable. The statistical significance of the variation in the parameters and the overall significance of the ordination were tested with the Monte-Carlo permutation test (as default settings of 499 unrestricted permutations; $p<0.05$ ). Ordination analyses were performed using CANOCO program, version 4.5 (Ter Braak and Smilauer, 2002).

\section{Results}

\subsection{Environmental parameters}

The values of the environmental parameters (depth, temperature, salinity, $\mathrm{pH}$, estimated phytoplankton biomass) in the studied lakes are given in Table 1. Temperature ranged from $12.30^{\circ} \mathrm{C}$ (AKRA1602 and OROB1503) to $27.20^{\circ} \mathrm{C}$ (MLAB1605). Maximum depth was low, less than $1 \mathrm{~m}$ for all the studied systems. Salinity ranged from $<2 \mathrm{ppt}$ (OROB1503 and OROA1605) to $300 \mathrm{ppt}$ (MLAB1605), and pH from 6.75 to 10.76 (MLAB1604 and PARB1503b, respectively). Total phytoplankton biomass ranged from $<0.01 \mathrm{mg} / \mathrm{L}$ (AERB1402 and AKRA1604) to $49.17 \mathrm{mg} / \mathrm{L}$ (OROA1603) (Tab. 1).

\subsection{Community composition and structure}

A total of 57 zooplankton taxa were identified in the studied lakes; 36 Rotifera, 13 Cladocera, five Copepoda, two Anostraca and some unidentified Ostracoda. The lowest species richness was recorded in Airport Lake (five taxa) and the highest in Lake Paralimni (35 taxa) (Fig. 2, Appendix). In hyposaline conditions (0-10 ppt), zooplankton communities were more diverse than in meso- and hyper- saline conditions (>70 ppt) (Fig. 3; Supplementary material, Tab. S1). More specifically, rotifers were more diverse in hyposaline conditions $(0-10 \mathrm{ppt})$, compared to mesosaline $(30-50 \mathrm{ppt})$ and slightly hypersaline $(50-70 \mathrm{ppt})$, while no rotifer was recorded in hypersaline conditions (>70 ppt) (Fig. 3). In hyposaline conditions $(0-10 \mathrm{ppt})$, crustacean communities were more diverse compared to meso- and slightly hypersaline conditions (30-70 ppt), mainly due to Cladocera, while no Cladocera were recorded in hypersaline conditions (>70 ppt) (Fig. 3). Among Copepoda, Arctodiaptomus salinus (Daday, 1885) was recorded at all salinity spectra (Fig. 3). In hyposaline conditions it co-existed with the cyclopoids Metacyclops minutus minutus (Claus, 1863) and Diacyclops bicuspidatus odessanus (Shmankevich, 1875), and unidentified harpacticoids (Fig. 3). For higher salinity values, $A$. salinus co-existed mostly with harpacticoids (Fig. 3). Anostraca were recorded only in sites with meso- hyper saline conditions (Fig. 3).

Total biomass ranged from $<0.01$ to $162.41 \mathrm{mg} / \mathrm{L}$, in Akrotiri Lake (AKRB1504) and Megali Larnaka (MLAB1604), respectively (Tab. 1). The crustacean community contributed at least $96 \%$ to the total biomass, given the low rotifer biomass (Fig. 4a). In Lake Paralimni and Lake Oroklini, where hyposaline conditions are occurring mainly, the crustacean community consisted mainly of copepods and cladocerans (Fig. 4a) and biomass ranged from $0.03 \mathrm{mg} / \mathrm{L}$ to 


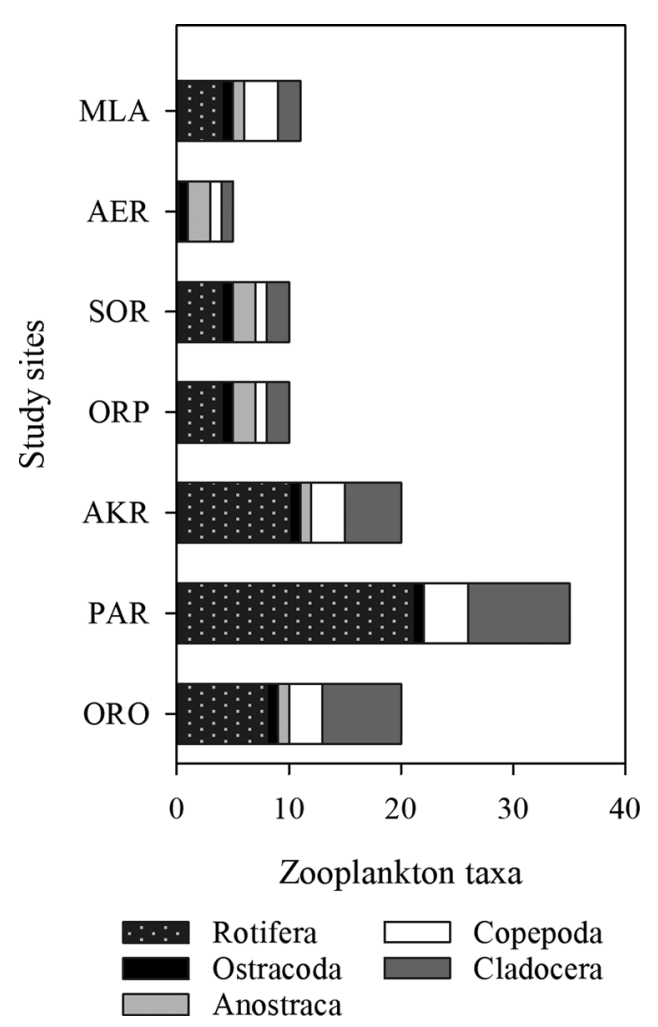

Fig. 2. Contribution of the zooplankton groups in the communities of seven lakes of Cyprus. Study sites abbreviations as shown in Figure 1.

$6.37 \mathrm{mg} / \mathrm{L}$, respectively (Tab. 1). The copepod community consisted almost exclusively of $A$. salinus in Lake Oroklini while in Lake Paralimni the cyclopoid M. minutus minutus was also dominant (Fig. 4a). The cladoceran community consisted almost exclusively of Daphnia (Ctenodaphnia) magna Straus, 1820 and Moina brachiata (Jurine, 1820) in Lake Oroklini while in Lake Paralimni Bosmina (Bosmina) longirostris (O.F. Müller, 1776) was also dominant (Fig. 4a).

In Larnaka Salt Lakes and Akrotiri Salt Lake, where mesoand hyper- saline conditions were occurring, in the cases where the anostracans Artemia salina (Linnaeus, 1758) and Phallocryptus spinosus (Milne-Edwards, 1840) were recorded their relative biomass was high from $44 \%$ to almost $100 \%$ in Megali Larnaka Lake (MLAA1505 and MLAA1402, MLAB1602, MLAB1604) and Airport Salt Lake (AERB1402) (Fig. 4a). When anostracans were not recorded, the crustacean community consisted mainly of the cladoceran $M$. brachiata in Megali Larnaka Lake (MLAB1505) and Akrotiri Salt Lake (AKRA1504) and of unidentified ostracods and the cladocerans D. magna and M. brachiata in Orphani Salt Lake (ORP1402 and ORP1604) and Akrotiri Salt Lake (AKRB1504), respectively (Fig. 4a).

The hierarchical cluster analysis (Fig. 4b) revealed that the zooplankton community structure differed significantly between samplings with varying salinity. Five groups were generated (ANOSIM, $R=0.92, p=0.01$ ). Samplings with low salinity fell in the upper band of cluster of sites (Group A; Fig. $4 \mathrm{~b}$ ), while those with medium and high salinity fell in the rest of the groups with no apparent pattern (Groups B, C, D, E; Fig. 4b). Groups A and E were significantly separated with each other and the rest of the groups as was shown by the pairwise comparison (ANOSIM, $R \geq 0.81, p<0.02$; Tab. S2). Their similarity is due mainly to the contribution of $A$. salinus and $D$. magna in Group A and in A. salina in Group E (Tab. S2).

The Species richness (S), Pielou's evenness index $(\mathrm{J})$ and Shannon's diversity index $\left(\mathrm{H}^{\prime}\right)$ for the zooplankton communities are shown in Figure 5. Indices $\mathrm{S}, \mathrm{J}$ and $\mathrm{H}^{\prime}$ differentiated significantly between the categories of salinity (ANOVA, $F=14.55, p<0.01, F=5.75, p<0.01$ and $F=7.21, p<0.05$, respectively) (Fig. 5). Pairwise test indicated that differences in $\mathrm{S}, \mathrm{J}$ and $\mathrm{H}^{\prime}$ between the hyposaline lakes and the rest with higher salinity values were significant $(p<0.05)$ (Fig. 5).

\subsection{Relationships between physical and chemical parameters and zooplankton communities' structure}

To assess significant relationships between environmental data and zooplankton's community structure, ordination analysis of taxa assemblages, expressed in terms of biomass was conducted (Fig. 6). In the diagnostic DCA the highest value of the length of gradient of axis was 4.28, which indicates that the relationship between the zooplankton and environmental variables was unimodal (Ter Braak and Smilauer, 2002), and a CCA was performed. The significant environmental variables $(p<0.05)$ included in the CCA were salinity, total phytoplankton biomass and water depth (Fig. 6). The Monte Carlo test confirmed that the selected CCA model was significant with $F$ ratio $=5.55(p<0.01)$. The eigenvalues of the first two axes were 0.63 and 0.47 , and both of them together explained $88.60 \%$ of the variation in speciesenvironment relation. The first axis, which accounted for a total variance of $51 \%$, was positively and strongly correlated with salinity $(r=0.95)$. Axis 2 showed $37.30 \%$ variation, and it was positively and strongly correlated with total phytoplankton biomass $(r=0.95)$. Depth was negatively and strongly correlated with the third axis $(r=-0.96)$, which accounted for a total of $11.40 \%$ variation.

\section{Discussion}

Saline lakes were largely being ignored by limnologists since few studies existed on the biota and associated processes of such lakes (Moss, 1994). Lately, though, there is an increase of interest to understand these ecosystems where life reaches its extremes. In the present study we investigated the structure of zooplankton community of seven saline Mediterranean lakes in relation to certain environmental parameters. As our data indicated, salinity was a key factor shaping both composition and structure of the zooplankton community in the studied lakes. Undoubtedly, the trophic state is an important factor affecting zooplankton community structure (Benndorf et al., 2002); in such systems though, salinity seems to play a more crucial role as a predominant driving force. Moreover, zooplankton communities differentiated across different years and seasons by salinity gradient even for the same water body. A crucial factor affecting the biological elements of saline lakes, and thus zooplankton is the hydrological budget (Williams, 2002). Still, differences in hydrological patterns are usually reflected in long-term or seasonal changes in salinity (Williams, 2002). Although, in our 


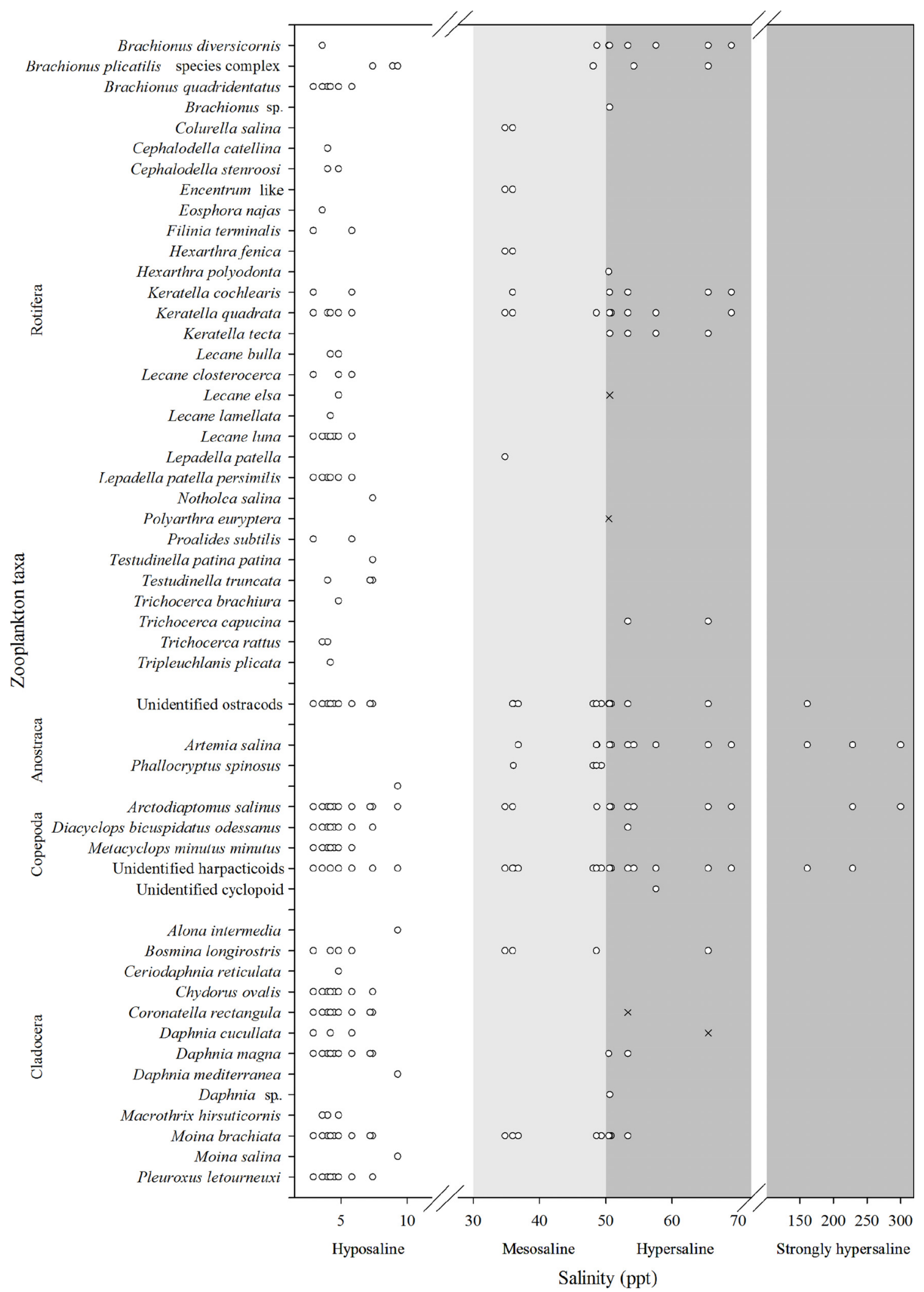

Fig. 3. Zooplankton taxa records in the recorded salinity gradient. Open circles indicate presence of each taxon in the seven studied lakes according to the in situ salinity values. White, light gray and dark gray areas indicate hyposaline, mesosaline and hypersaline conditions, respectively. X mark indicates typically freshwater taxa recorded. 

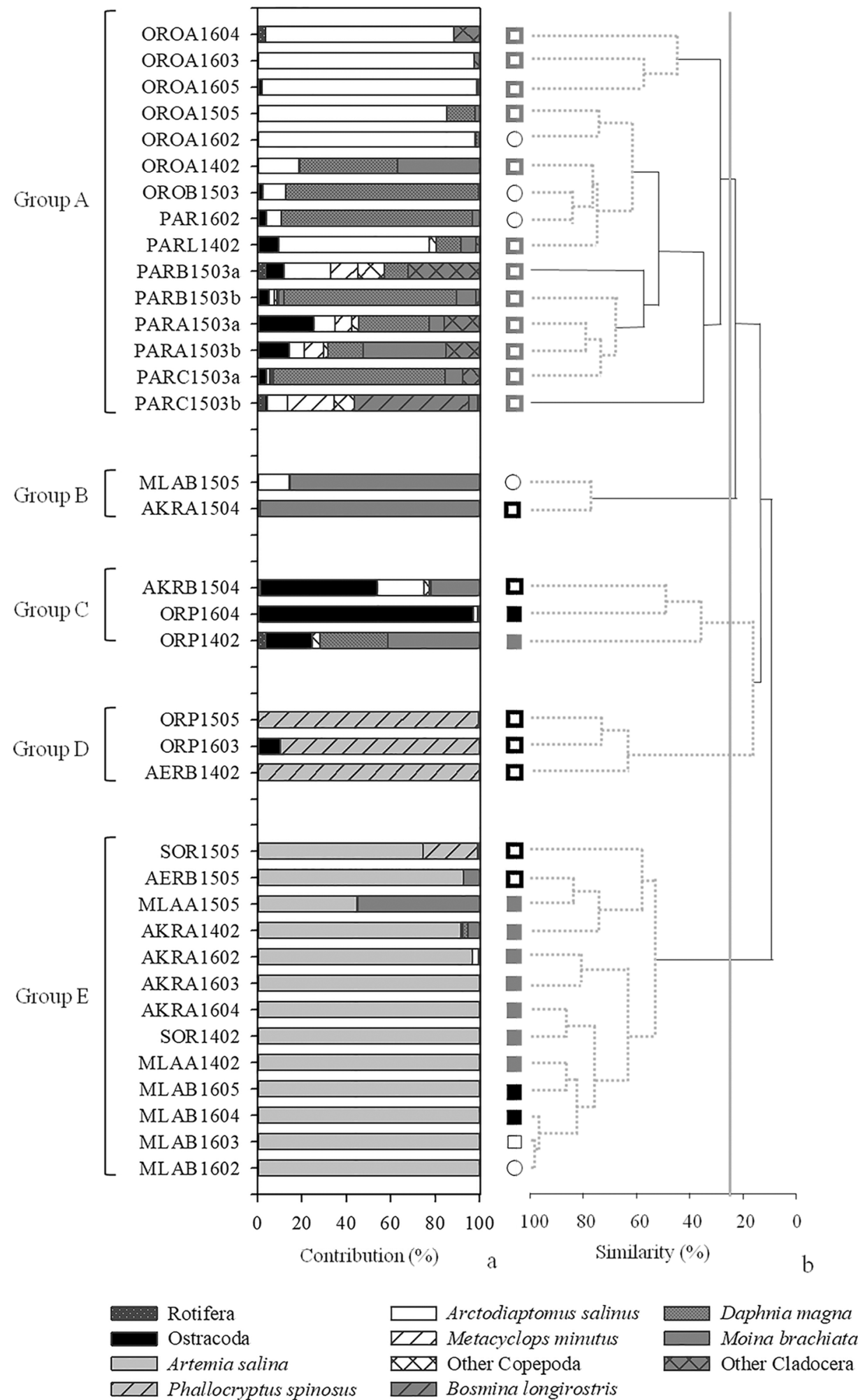

Fig. 4. (a) Percentage contribution of dominant zooplankton taxa to total biomass in the studied lakes in Cyprus. (b) Dendogram of Bray-Curtis similarity index of zooplankton community among samplings in the studied lakes of Cyprus from hierarchical agglomerative cluster analysis in $\log x+1$ transformed data of zooplankton taxa's biomass at level of similarity $25 \%$, as indicated by the solid gray line. Solid black lines indicate significant branches based on SIMPROF permutation tests, while dashed gray lines indicate non-significant divisions. Symbols coded for salinity category open gray square for hyposaline $(0-10 \mathrm{ppt})$, open black square for mesosaline $(30-50 \mathrm{ppt})$, gray filled square for slightly hypersaline $(50-70 \mathrm{ppt})$ and black filled square for strongly hypersaline ( $>70 \mathrm{ppt})$ conditions. Samplings abbreviations as shown in Table 1 . 

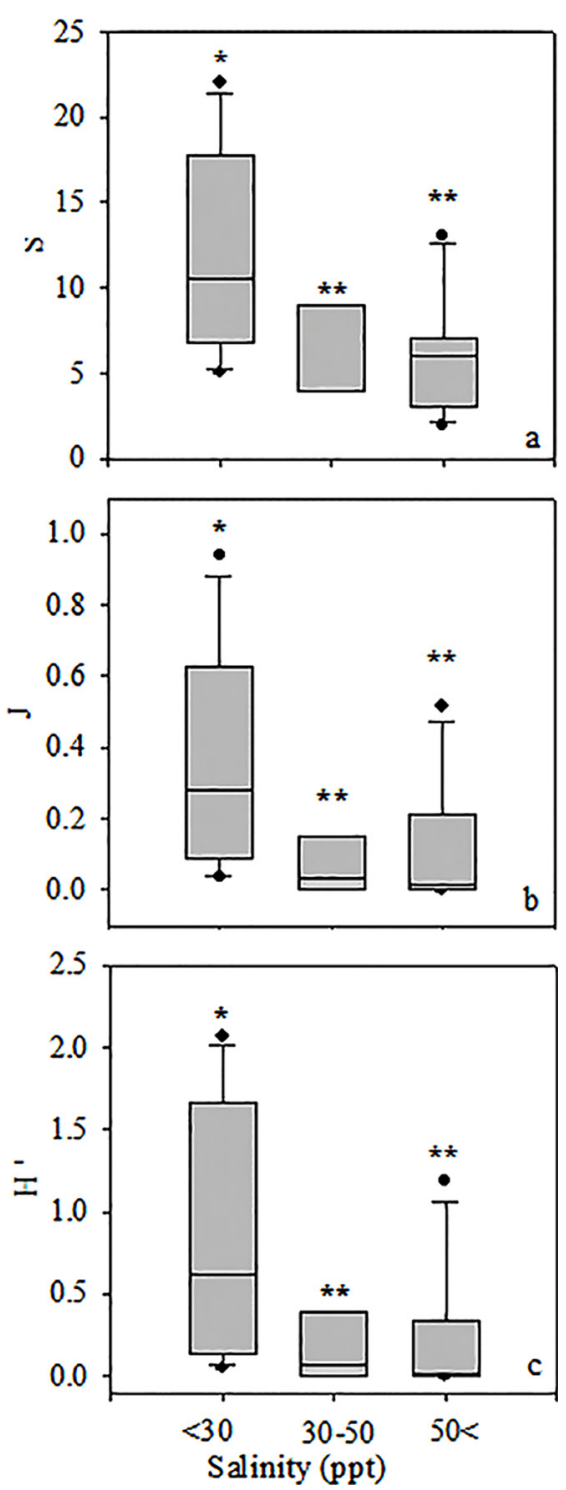

Fig. 5. Box plots of Species richness (S), Pielou's eveness index (J) and Shannon diversity index $\left(\mathrm{H}^{\prime}\right)$ for the zooplankton community of the seven lakes in Cyprus calculated for biomass data grouped by salinity $(p<0.05) . *{ }^{*}$, Significant differences (Fisher's LSD test).

study, the snapshot samplings did not provide enough data concerning the hydrological budget in order to reach sound conclusions related to this parameter, our data share the major patterns that have been described in shallow temporary lakes with high salinity (e.g., Alonso, 1990; Brucet et al., 2005, Waterkeyn et al., 2008).

Regarding zooplankton composition, the distribution of some taxa is largely explained by their physiological adaptations to salinity (Derry et al., 2003). For example, the rotifers encountered in the studied lakes, based on the categories of Fontaneto et al. (2006), were mainly euryhaline species [e.g., Brachionus quadridentatus Hermann, 1783; Keratella quadrata (Müller, 1786)], haloxenous [e.g., Brachionus diversicornis (Daday, 1883); Colurella salina Althaus, 1957; Hexarthra polyodonta (Hauer, 1957)], strictly saline [e.g., Brachionus plicatilis species complex; Lecane lamellata

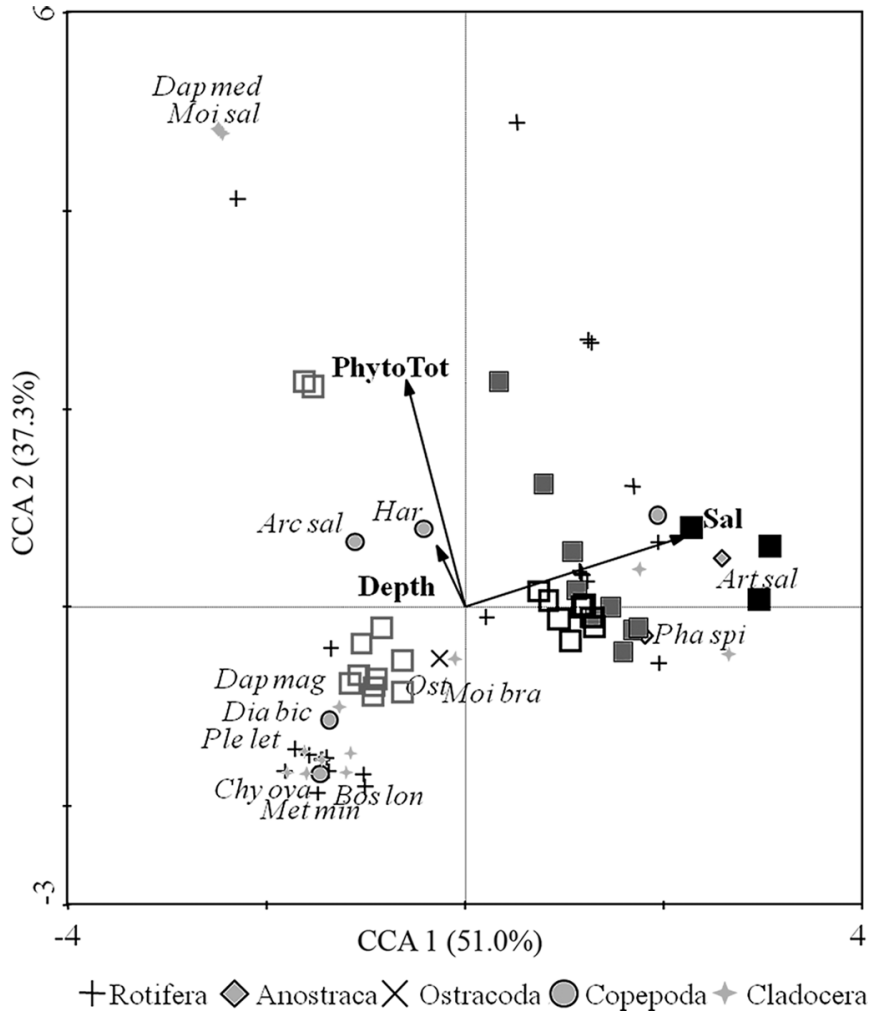

Fig. 6. Triplot diagram of zooplankton species, explanatory variables and samples in a canonical correspondence analysis (CCA) of the first and second canonical axis illustrating the relationships among communities in the studied lakes in Cyprus. Square points indicate the position of zooplankton communities in relation to environmental parameters (solid arrows) and species composition (data points) based on taxa's biomass. Samplings were coded based on salinity categories same as in Figure $4 b$. Labelled taxa indicate the taxa that contributed in similarity and dissimilarity among samplings according to SIMPER analysis (Supplementary Tab. S2); Artemia salina (Art sal), Arctodiaptomus salinus (Arc sal), Bosmina longirostris (Bos lon), Chydorus ovalis (Chy ova), Daphnia magna (Dap mag), Daphnia mediterranea (Dap med), Diacyclops bicuspidatus odessanus (Dia bic), Unidentified harpacticoids (Har), Metacyclops minutus minutus (Met min), Moina brachiata (Moi bra), Moina salina (Moi sal), unidentified ostracods (Ost), Phallocryptus spinosus (Pha spi), Pleuroxus letourneuxi (Ple let).

(Daday, 1893); Notholca salina Focke, 1961] or freshwater stenohaline species (e.g., Cephalodella intuta Myers, 1924) depending on the recorded salinity (Fig. 3). According to Ruttner-Kolisko (1971), for rotifers, after the salinity threshold of $1.50 \mathrm{ppt}$, the biocenosis is changing characteristically and this adaptation is reflected in the taxonomic composition of zooplankton communities of Mediterranean arid regions as was also shown in our study. In the crustacean communities, species with high salinity tolerance were mainly recorded. Among cladocerans, most species that have been recorded in the studied lakes are typical of temporary saline lakes in the Mediterranean arid regions [e.g., Alona intermedia Sars, 1862; Daphnia (Ctenodaphnia) mediterranea Alonso, 1985; Ceriodaphnia reticulata (Jurine, 1820); Coronatella rectangula (Sars, 1862); Macrothrix hirsuticornis Norman \& Brady, 
1867; M. brachiata; Moina salina Daday, 1888; Pleuroxus letourneuxi (Richard, 1888)] (Alonso, 1990; Eitam et al., 2004; Marrone et al., 2006; Benvenuto et al., 2015) and also typical of freshwater habitats, such Daphnia cucullata Sars, 1862; while the Copepoda community was less diverse, comprising the calanoid copepod A. salinus, unidentified harpacticoids and two cyclopoid copepods which are typically found in temporary ponds, (Alonso, 1990; Benvenuto et al., 2015). A. salinus was recorded in all salinity spectra in the present study, reflecting its adaptation in a wide range of salinity conditions (Svetlichny et al., 2012). Finally, the anostracan genera Artemia and Phallocryptus were recorded only in sites with meso- hyper saline values, reflecting their adaptation in hypersaline water bodies (Alonso, 1990). In total, hyposaline lakes were more diverse not only in terms of species richness, but also in terms of Pielou's eveness index (J) and Shannon diversity index $\left(\mathrm{H}^{\prime}\right)$ in agreement with Moss (1994) and Brucet et al. (2009).

Likewise, salinity was an important shaping factor in zooplankton community structure. Regardless of salinity range, rotifer contribution to total biomass was low, due to their small size. Thus in terms of biomass crustaceans dominated. In hyposaline conditions, biomass was dominated by $A$. salinus, $D$. magna and $M$. brachiata. A. salinus dominance may be linked to its ability to better exploit available food. In particular, this copepod has been commonly described as herbivorous (Tolomeyev, 2002) and as a predator of small zooplankters, such as Brachionus species in adult stages (Lapesa et al., 2004). Compared to D. bicuspidatus odessanus, which co-existed with A. salinus in the present study, it is a more efficient and less selective predator (Lapesa et al., 2004). The large sized $D$. magna dominated in total biomass under hyposaline conditions due to its optimal individual growth rate, reproductive output and population growth rate, which are high at salinities near $4 \mathrm{ppt}$ (Arnér and Koivisto, 1993) and its high filter feeding efficiency consuming both bacteria and algae (Gophen, 1977; Geller and Müller, 1981) outcompeting the rest of the filter feeders. Based on investigation of life history traits (development, reproduction and growth pattern) in M. brachiata, Maier (1992) concluded that the species has a relatively short egg development period and high egg production rates that are advantageous in fluctuating environments. Thus, M. brachiata was favored by the hydrological conditions of the studied systems. In meso- and hypersaline conditions ( $>70 \mathrm{ppt})$, in some cases communities were dominated by anostracans (mostly over $90 \%$ in total biomass). In general, Anostraca tend to dominate temporary water bodies in early successional phases (Jocque et al., 2010) because of their effective feeding strategy (Dumont and Ali, 2004). In the cases that anostracans were absent in the studied lakes, dominance of $A$. salinus, M. brachiata and ostracods (Fig. 4a) indicated a reverse relationship between anostracans and other filter feeders. This could be due to the competitive dominance of anostracans that suggests that they may be able to outcompete cladocerans and other filter feeders (Jocque et al., 2010).

Competitive interactions seem to be the drivers affecting zooplankton community structure in these systems as opposed to freshwater lakes where fish predation is the major driving factor (Lampert and Sommer, 2007). In fishless aquatic habitats, competition for resources among zooplankton is stated as the rapid exclusion of competitively inferior species, which leads to dominance of a single or a few large body-sized species size, such as the cladoceran Daphnia and/or the anostracan Artemia in higher densities than in habitats with the presence of fish (Gliwicz et al., 2010). Temporary and/or highly saline lakes are mostly unsuitable habitats for fish; thus, Mediterranean temporary saline lakes are either entirely fishless or fish presence is limited during the flood period (Gutiérrez-Yurrita et al., 1998) or they serve as pathways for fish migration towards more suitable habitats, as is the case in e.g. Akrotiri lake.

Overall, the presence and dominance of specific zooplankton taxa in a wide range of salinity was recorded in the studied lakes. This may be either due to the physiological adaptation of species in fluctuating salinity of temporary lakes or/and to the presence of cryptic species complexes with different halopreferenda. For example, genetic research on $M$. brachiata recently revealed that under this binomen might actually be included four cryptic species contistuting the $M$. brachiata complex, and difference in species occurrences are associated with salinity and hydroperiod (Nédli et al., 2014). Moreover, despite the fact that $A$. salinus is thought to be an euryhaline species (Svetlichny et al., 2012), indications exist for the presence of cryptic species under this binomen (Anufriieva and Shadrin, 2014). Thus, more attention needs to be paid to study the phenotypic and genetic diversity in these zooplankton populations.

This is the first detailed study on the structure and dynamics of the zooplankton community of saline lakes in Cyprus. One more study exists by Balık et al. (2008), but their research was limited in the northern part of the island and dealt with freshwater reservoirs. In certain regions, such as the sensitive to climate change arid Mediterranean, many seasonally-filled saline lakes are likely to experience dryness for longer periods in the future (Williams, 2002). This will probably be the case for saline lakes of Cyprus. The implementation of effective management and conservation measures has to consider the special ecological features and requirements of these unique ecosystems; thus a solid basis built on ecological knowledge is required.

Our results support the importance of salinity as a major driver of zooplankton community composition and structure in saline lakes. Therefore, we propose that salinity should be considered a key factor for typological considerations in quality assessments, restoration and management plans, the development of indices indicating the water quality and even the establishment of reference conditions according to the WFD in these temporary saline systems. Moreover, despite the fact that zooplankton is not a standard biological element according to the WFD (European Commission, 2000), it should be considered as one, since it reflects environmental pressures (Bagella et al., 2010), is a key shaping factor in the fishless Mediterranean temporary saline lakes; and is largely affected by the salinity gradient.

Acknowledgments. The present work forms part of a research project financed by Water Development Department of Republic of Cyprus through the programs "YY06/2013Identification of reference conditions in lake water bodies according to the Programme of Measures (Measure 142) and update of the classification of the water body types according to the provisions of the WFD" and "YY02/2016 - Updating 
the identification of reference conditions in lake water bodies and updating the classification of water body types according to the provisions of the WFD and based on the results of the contract YY 06/2013". Finally, we would like to thank the two anonymous reviewers for their suggestions and comments.

\section{References}

Alonso M. 1990. Anostraca, Cladocera and Copepoda of Spanish saline lakes. Hydrobiologia 197: 221-231.

Alonso M. 1996. Crustacea Branchiopoda. In: Ramos Sánchez MA, ed. Fauna Iberica 7. Madrid: Museo Nacional de Ciencias Naturales CSIC.

Amoros C. 1984. Crustacés Cladocères. Lyon: Bulletin Mensuel de la Société Linnéenne.

Anh NTN, Van Hoa N, Van Stappen G, Sorgeloos P. 2009. Effect of different supplemental feeds on proximate composition and Artemia biomass production in salt ponds. Aquaculture 286: 217-225.

Anufriieva EV, Shadrin NV. 2014. Factors determining the average body size of geographically separated Arctodiaptomus salinus (Daday, 1885) populations. Zool Res 35: 132-141.

Arnér M, Koivisto S. 1993. Effects of salinity on metabolism and life history characteristics of Daphnia magna. Hydrobiologia 259: 6977.

Azevedo FD, Dias JD, Braghin LDSM, Bonecker CC. 2012. Lengthweight regressions of the microcrustacean species from a tropical floodplain. Acta Limnol Bras 24: 01-11.

Bagella S, Gascón S, Caria MC, Sala J, Mariani MA, Boix D. 2010. Identifying key environmental factors related to plant and crustacean assemblages in Mediterranean temporary ponds. Biodivers Conserv 19: 1749-1768.

Balık S, Ustaoglu MR, Mis DÖ, Aygen C, Tasdemir A, İlhan A. 2008. Kuzey Kıbrıs Türk Cumhuriyeti tatlı su göletlerinin sucul faunası üzerine ilk gözlemler. EÜ Su Ürünleri Derg 25: 347-351.

Benndorf J, Böing W, Koop J, Neubauer I. 2002. Top-down control of phytoplankton: the role of time scale, lake depth and trophic state. Freshwater Biol 48: 2282-2295.

Benvenuto C, Knott B, Weeks SC. 2015. Crustaceans of extreme environments. In: Thiel M, Watling L, eds. Lifestyles and feeding biology. New York: Oxford University Press, pp. 379-417.

Benzie JAH. 2005. The Genus Daphnia (Including Daphniopsis). In: Dumont HJF, ed. Guides to the identification of the microinvertebrates of the continental waters of the world 21. Leiden (The Netherlands): Kenobi Productions, Ghent, Belgium and Backhuys Publishers.

Boix D, Gascón S, Sala J, Martinoy M, Gifre J, Quintana XD. 2005. A new index of water quality assessment in Mediterranean wetlands based on crustacean and insect assemblages: the case of Catalunya (NE Iberian peninsula). Aquat Conserv Mar Freshw Ecosyst 15: 635-651.

Boronat L, Miracle MR, Armengol X. 2001. Cladoceran assemblages in a mineralization gradient. Hydrobiologia 442: 75-88.

Bottrell HH, Duncan A, Gliwicz ZM, Grygierek E, Herzig A, Hillbright-Ilkowska A, Kurasawa H, Larsson P, Weglenska T. 1976. A review of some problems in zooplankton production studies. Nor J Zool 24: 419-456.

Bray JR, Curtis JT. 1957. An ordination of the upland forest communities of southern Wisconsin. Ecol Monogr 27: 325-349.

Brock MA, Nielsen DL, Shiel RJ, Green JD, Langley JD. 2003. Drought and aquatic community resilience: the role of eggs and seeds in sediments of temporary wetlands. Freshw Biol 48: 1207-1218.
Brtek J, Mura G. 2000. Revised key to families and genera of the Anostraca with notes on their geographical distribution. Crustaceana 73: 1037-1088.

Brucet S, Boix D, López-Flores R, Badosa, A, Moreno-Amich R, Quintana XD. 2005. Zooplankton structure and dynamics in permanent and temporary Mediterranean salt marshes: taxon-based and size-based approaches. Arch Hydrobiol 162: 535-555.

Brucet S, Boix D, Gascón S, Sala J, Quintana XD, Badosa A, Søndergaard M, Lauridsen TL, Jeppesen E. 2009. Species richness of crustacean zooplankton and trophic structure of brackish lagoons in contrasting climate zones: north temperate Denmark and Mediterranean Catalonia (Spain). Ecography 32: 692-702.

Brucet S, Boix D, Quintana XD, Jensen E, Nathansen LW, Trochine C, Meerhoff M, Gascón S, Jeppesen E. 2010. Factors influencing zooplankton size structure at contrasting temperatures in coastal shallow lakes: implications for effects of climate change. Limnol Oceanogr 55: 1697-1711.

Clarke KR, Gorley RN. 2006. PRIMER v6: user manual/tutorial. Plymouth: PRIMER-E, 115 p.

Council of the European Commission. 1992. Council directive 92/43/ EEC of 21 May 1992 on the conservation of natural habitats and of wild fauna and flora. Official Journal of the European Communities, Brussels, Series L 206, 7-49.

Davis JS. 2000. Structure, function, and management of the biological system for seasonal solar saltworks. Glob NEST J 2: 217-226.

Derry AM, Prepas EE, Hebert PDN. 2003. A comparison of zooplankton communities in saline lakewater with variable anion composition. Hydrobiologia 505: 199-215.

Dumont HJ, Ali AJ. 2004. Stage-specific cannibalism and spontaneous cyst hatching in the freshwater fairy shrimp Streptocephalus proboscideus Frauenfeld. Hydrobiologia 524: 103-113.

Dumont HJ, Van de Velde I, Dumont S. 1975. The dry weight estimate of biomass in a selection of Cladocera, Copepoda and Rotifera from the plankton, periphyton and benthos of continental waters. Oecologia 19: 75-97.

Dussart B. 1967. Les copépodes des eaux continentales d'Europe occidentale. In: Tome II: Cyclopoïdes et Biologie. Paris: Editions N. Boublée \& Cie.

Dussart BH, Defaye D. 2001. Introduction to the Copepoda. In: Dumont HJF, ed. Guides to the identification of the macroinvertebrates of the continental waters of the world 16. Leiden (The Netherlands): Backhuys Publishers.

Einsle U. 1996. Copepoda: Cyclopoida Cyclops, Megacyclops, Acanthocyclops. In: Dumont HJF, ed. Guides to the Identification of the Microinvertebrates of the continental waters of the world 10 . Amsterdam (The Netherlands): SPB Academic Publishing bv.

Eitam A, Blaustein L, Van Damme K, Dumont HJ, Martens K. 2004. Crustacean species richness in temporary pools: relationships with habitat traits. Hydrobiologia 525: 125-130.

Eugster HP, Hardie LA. 1978. Saline lakes. In: Lerman A, ed. Lakes. New York: Springer-Verlag, pp. 237-293.

European Commission. 2000. Directive 2000/60/EC of the European Parliament and of the Council - establishing a framework for Community action in the field of water policy. Brussels: European Commission.

Fontaneto D, De Smet WH, Ricci C. 2006. Rotifers in saltwater environments, re-evaluation of an inconspicuous taxon. J Mar Biol Assoc UK 86: 623-656.

Geller W, Müller H. 1981. The filtration apparatus of Cladocera: filter mesh-sizes and their implications on food selectivity. Oecologia 49: $316-321$.

Gilbert JD, de Vicente I, Jiménez-Melero R, Parra G, Guerrero F. 2014. Selecting priority conservation areas based on zooplankton 
diversity: the case of Mediterranean wetlands. Mar Freshw Res 65: 857-871.

Gliwicz ZM, Wursbaugh WA, Szymanska E. 2010. Absence of predation eliminates coexistence: experience from the fishzooplankton interface. Hydrobiologia 653: 103-117.

González EJ, Matsumura-Tundisi T, Tundisi JG. 2008. Size and dry weight of main zooplankton species in Bariri reservoir (SP, Brazil). Braz J Biol 68: 69-75.

Gophen M. 1977. Feeding of Daphnia on Chlamydomonas and Chlorobium. Nature 265: 271-273.

Gutiérrez-Yurrita PJ, Sancho G, Bravo MA, Baltanás A, Montes C. 1998. Diet of the red swamp crayfish Procambarus clarkia in natural ecosystems of the Doñana National Park temporary freshwater marsh (Spain). J Crustac Biol 18: 120-127.

Haberman J. 1976a. An ecological characterization of the rotifers dominating in the pelagic region of lakes Peipsi-Pihkva and Võrtsjärv. In: Haberman $\mathrm{H}$, Haberman $\mathrm{J}$, Elberg $\mathrm{K}$, eds. Productivity of Estonian fresh waters, Estonian Contributions to the International Biological Programme. Vol. 10, Tartu, pp. 35-59.

Haberman J. 1976b. An ecological characterization of the crustaceans (Cladocera, Copepoda) and Dreissena polymorpha juv. dominating in the pelagic region of lakes Peipsi-Pihkva and Võrtsjärv. In: Haberman H, Haberman J, Elberg K, eds. Productivity of Estonian fresh waters, Vol. 10, Estonian Contributions to the International Biological Programme, Tartu, pp. 60-99.

Haberman J, Haldna M. 2014. Indices of zooplankton community as valuable tools in assessing the trophic state and water quality of eutrophic lakes: long term study of Lake Võrtsjärv. J Limnol 73: 263-273.

Hairston NG. 1996. Zooplankton egg banks as biotic reservoirs in changing environments. Limnol Oceanogr 41: 1087-1092.

Hammer UT. 1986. Saline lake ecosystems of the world. Dordrecht: Dr. W. Junk Publishers, 616 p.

Hillebrand H, Dürselen CD, Kirschtel D, Pollingher U, Zohary T. 1999. Biovolume calculation for pelagic and benthic microalgae. $J$ Phycol 35: 403-424.

Huber-Pestalozzi G. 1938. Das Phytoplankton des Susswassers. Systematik und Biologie. In: Thienemann A, ed. Die Binnengewasser. Stuttgart: Schwezerbart.

Jarecki L, Walkey M. 2006. Variable hydrology and salinity of salt ponds in the British Virgin Islands. Saline Syst 2. DOI:10.1186/ 1746-1448-2-2.

Jeppesen E, Nõges P, Davidson TA, Haberman J, Nõges T, Blank K, Lauridsen TL, Søndergaard M, Sayer C, Laugaste R, Johansson LS, Bjerring R, Amsinck SL. 2011. Zooplankton as indicators in lakes: a scientific-based plea for including zooplankton in the ecological quality assessment of lakes according to the European Water Framework Directive (WFD). Hydrobiologia 676: 279-297.

Jocque M, Vanschoenwinkel B, Brendonck L. 2010. Anostracan monopolisation of early successional phases in temporary waters. Fundam Appl Limnol 176: 127-132.

Ketmaier V, Pirollo D, De Matthaeis E, Tiedemann R, Mura G. 2008. Large-scale mitochondrial phylogeography in the halophilic fairy shrimp Phallocryptus spinosa (Milne-Edwards, 1840) (Branchiopoda: Anostraca). Aquat Sci 70: 65-76.

Khemakhem H, Elloumi J, Moussa M, Aleya L, Ayadi H. 2010. The concept of ecological succession applied to phytoplankton over four consecutive years in five ponds featuring a salinity gradient. Estuar Coast Shelf Sci 88: 33-44.

Kiefer F. 1971. Revision der bacillifer - gruppe der gattung Arctodiaptomus Kiefer (Crustacea Copepoda: Calanoida). Mem Ist Ital Idrobiol 27: 113-267.
Kirono DG, Kent DM, Jones RN, Leahy PJ. 2012. Assessing climate change impacts and risks on three salt lakes in western Victoria, Australia. Hum Ecol Risk Assess 18: 152-167.

Koste W. 1978. Rotatoria, die Rãdertiere Mitteleuropas. Berlin, Stuggart: Gebrüder Borntraeger.

Lampert W, Sommer U. 2007. Limnoecology: the ecology of lakes and streams, 2nd ed. New York: Oxford University Press Inc., $324 \mathrm{p}$.

Lapesa S, Snell TW, Fields DM, Serra M. 2004. Selective feeding of Arctodiaptomus salinus (Copepoda, Calanoida) on co-occurring sibling rotifer species. Freshw Biol 49: 1053-1061.

LAWA. 2003. German Guidance document for the implementation of the EC Water Framework Directive. Länderarbeitsgemeinschaft Wasser, Mainz, Germany. http://www.lawa.de/Publikationen.html.

Maier G. 1992. Development, reproduction and growth pattern of two coexisting, pond dwelling cladocerans. Int Rev Hydrobiol 77: 621632.

Maier G. 1994. Patterns of life history among cyclopoid copepods of central Europe. Freshw Biol 31: 77-86.

Marques SC, Pardal MÂ, Mendes S, Azeiteiro UM. 2011. Using multitable techniques for assessing the temporal variability of species-environment relationship in a copepod community from a temperate estuarine ecosystem. J Exp Mar Biol Ecol 405: 59-67.

Marrone F, Barone R, Naselli-Flores L. 2006. Ecological characterization and cladocerans, calanoid copepods and large branchiopods of temporary ponds in a Mediterranean island (Sicily, Southern Italy). Chem Ecol 22: 181-190.

Michaloudi E. 2005. Dry weights of the zooplankton of Lake Mikri Prespa (Macedonia, Greece). Belg J Zool 135: 223-227.

Moss B. 1994. Brackish and freshwater shallow lakes - different systems or variations on the same theme. Hydrobiologia 275: 1-14.

Moss B, Stephen D, Álvarez C, Bécares E, van de Bund W, Collings SE, van Donk E, de Eyto E, Feldmann T, Fernández-Aláez C, Fernández-Aláez M, Franken RJM, García-Criado F, Gross EM, Gyllström M, Hansson L-A, Irvine K, Järvalt A, Jensen J-P, Jeppesen E, Kairesalo T, Kornijów R, Krause T, Künnap H, Laas A, Lill E, Lorens B, Luup H, Miracle MR, Nõges P, Nõges T, Nykänen M, Ott I, Peczula W, Peeters ETHM, Phillips G, Romo S, Russell V, Salujõe J, Scheffer M, Siewertsen K, Smal H, Tesch C, Timm H, Tuvikene L, Tonno I, Virro T, Vicente E, Wilson D. 2003. The determination of ecological status in shallow lakes - a tested system (ECOFRAME) for implementation of the European Water Framework Directive. Aquat Conserv Mar Freshw Ecosyst 13: 507-549.

Munoz J, Gomez A, Green AJ, Figuerola J, Amat F, Rico C. 2008. Phylogeography and local endemism of the native Mediterranean brine shrimp Artemia salina (Branchiopoda: Anostraca). Mol Ecol 17: 3160-3177.

Mura G, Hadjstephanou N. 1987. First records of Branchinella spinosa Milne-Edwards (Crustacea, Anostraca) in Cyprus. Riv Idrobiol 26: 1-3.

Nédli J, De Meester L, Major Á, Schwenk K, Szivák I, Forró L. 2014. Salinity and depth as structuring factors of cryptic divergence in Moina brachiata (Crustacea: Cladocera). Fundam Appl Limnol 184: 69-85.

Nogrady T, Segers H. 2002. Rotifera 6. The Asplanchnidae, Gastropodidae, Lindiidae, Microcodinidae, Synchaetidae, Trochosphaeridae and Filinia. In: Dumont HJF, ed. Guides to the Identification of the Microinvertebrates of the Continental Waters of the World 18. Leiden (The Netherlands): Backhuys Publishers.

Nogrady T, Pourriot R, Segers H. 1995. Rotifera 3. The notommatidae and the scaridiidae. In: Dumont HJF, ed. Guides to the identification of the microinvertebrates of the continental waters 
of the world 8. Amsterdam (The Netherlands): SPB Academic Publishing BV.

O'Connell M, Young J, Kingwell R. 2006. The economic value of saltland pastures in a mixed farming system in Western Australia. Agric Syst 89: 371-389.

Pielou EC. 1969. An introduction to mathematical ecology. New York: Wiley-Interscience, 294 p.

Reddy RY. 1994. Copepoda: Calanoida: Diaptomidae. In: Dumont HJF, ed. Guides to the identification of the microinvertebrates of the continental waters of the world 5. The Hague (The Netherlands): SPB Academic Publishing.

Rott E. 1981. Some results from phytoplankton counting intercalibrations. Schweiz Z Hydrol 43: 34-62

Ruttner-Kolisko A. 1971. Rotatorien als indikatoren für den chemismus von binnensalzgewässern. sitzungsberichte der österreichische akademie der wissenschaften in wien. Mathematisch Naturwissenschaftliche Klasse. Abteilung 1: 179: 283-298.

Segers H. 1995. Rotifera 2: the lecanidae (monogononta). In: Dumond HJF, ed. Guides to the identification of the microinvertebrates of the continental waters of the world 6. The Hague (The Netherlands): SPB Academic Publishing.

Shannon CE. 1948. A mathematical theory of communication, Part I, Part II. Bell Syst Tech J 27: 623-656.

Smith VH. 2003. Eutrophication of freshwater and coastal ecosystems. A global problem. Environ Sci Pollut Res 10: 126-139.

Stenger-Kovács C, Lengye E, Buczkó K, Tóth FM, Crossetti LO, Pellinger A, Zámbóné ZD, Padisák J. 2014. Vanishing world: alkaline, saline lakes in Central Europe and their diatom assemblages. Inland Waters 4: 383-396.

Svetlichny L, Hubareva E, Khanaychenko A. 2012. Calanipeda aquaedulcis and Arctodiaptomus salinus are exceptionally euryhaline osmoconformers: evidence from mortality, oxygen consumption, and mass density patterns. Mar Ecol Prog Ser 470: $15-29$.

Tikkanen T. 1986. Kasviplanktonopas. Suomen Luonnonsuojelun Tuki Oy, Helsinki. pp. 104-113 [in Finish].

Ter Braak CJF, Smilauer P. 2002. CANOCO Reference Manual and CanoDraw for Windows User's Guide: Software for Canonical
Community Ordination, version 4.5. Microcomputer Power, Ithaca, NY, $500 \mathrm{p}$.

Ter Braak CJ, Verdonschot PF. 1995. Canonical correspondence analysis and related multivariate methods in aquatic ecology. Aquat Sci 57: 255-289.

Tolomeyev AP. 2002. Phytoplankton diet of Arctodiaptomus salinus (Copepoda, Calanoida) in Lake Shira (Khakasia). Aquat Ecol 36: 229-234.

Torrentera L, Dodson SI. 2004. Ecology of the brine shrimp Artemia in the Yucatan, Mexico, salterns. J Plankton Res 26: 617-624.

Tziortzis I, Zogaris S, Papatheodoulou A, Marrone F. 2014. First record of the Tadpole Shrimp Triops cancriformis (Branchiopoda, Notostraca) in Cyprus. Limnetica 33: 341-348.

Utermöhl H. 1958. Vervollkommung der quantitativen Phytoplankton-methodik. Mitt Int Ver Theor Angewan Limnol 9: 1-38.

Vieira N, Bio A. 2011. Spatial and temporal variability of water quality and zooplankton in an artisanal salina. J Sea Res 65: 293 303.

Waterkeyn A, Grillas P, Vanschoenwinkel B, Brendonck L. 2008. Invertebrate community patterns in Mediterranean temporary wetlands along hydroperiod and salinity gradients. Freshw Biol 53: 1808-1822.

Williams WD. 1985. Biotic adaptations in temporary lentic waters, with special reference to those in semi-arid and arid regions. Hydrobiologia 125: 85-110.

Williams WD. 1993. Conservation of salt lakes. Hydrobiologia 267: 291-306.

Williams WD. 1998. Salinity as a determinant of the structure of biological communities in salt lakes. Hydrobiologia 381: 191-201.

Williams WD. 2002. Environmental threats to salt lakes and the likely status of inland saline ecosystems in 2025. Environ Conserv 29: 154-167.

Zacharias I, Zamparas M. 2010. Mediterranean temporary ponds. A disappearing ecosystem. Biodivers Conserv 19: 3827-3834.

Zacharias I, Dimitriou E, Dekker A, Dorsman E. 2007. Overview of temporary ponds in the Mediterranean region: threats, management and conservation issues. J Environ Biol 28: 1-9.

Cite this article as: Karagianni A, Stamou G, Katsiapi M, Polykarpou P, Dörflinger G, Michaloudi E. 2018. Zooplankton communities in Mediterranean temporary lakes: the case of saline lakes in Cyprus. Ann. Limnol. - Int. J. Lim. 54: 14 
Table A1. List of recorded taxa per study site in seven lakes of Cyprus. Open cycles indicate absence and solid black cycles presence of taxa. Study sites abbreviations as shown in Figure 1.

\begin{tabular}{|c|c|c|c|c|c|c|c|}
\hline & MLA & AER & SOR & ORP & AKR & PAR & ORO \\
\hline Brachionus diversicornis (Daday, 1883) & 0 & O & 0 & 0 & 0 & 0 & 0 \\
\hline Brachionus plicatilis species complex & 0 & 0 & 0 & 0 & 0 & $\mathrm{O}$ & 0 \\
\hline Brachionus quadridentatus Hermann, 1783 & O & 0 & O & O & 0 & 0 & O \\
\hline Brachionus sp. Pallas, 1766 & O & O & 0 & O & O & $\mathrm{O}$ & O \\
\hline Colurella salina Althaus, 1957 & 0 & 0 & 0 & 0 & 0 & 0 & 0 \\
\hline Cephalodella catellina (Müller, 1786) & 0 & 0 & 0 & 0 & 0 & 0 & 0 \\
\hline Cephalodella stenroosi Wulfert, 1937 & 0 & O & O & O & O & 0 & O \\
\hline Cephalodella intuta Myers, 1924 & 0 & 0 & 0 & 0 & 0 & 0 & 0 \\
\hline Encertum like & 0 & 0 & 0 & 0 & 0 & 0 & 0 \\
\hline Keratella cochlearis (Gosse, 1851) & O & O & 0 & 0 & 0 & 0 & 0 \\
\hline Keratella quadrata (Müller, 1786) & 0 & 0 & 0 & 0 & 0 & 0 & 0 \\
\hline Keratella tecta (Gosse, 1851) & 0 & 0 & 0 & 0 & 0 & 0 & 0 \\
\hline Lecane bulla (Gosse, 1851) & O & O & O & O & O & 0 & O \\
\hline Lecane closterocerca (Schmarda, 1859) & O & O & $\bigcirc$ & O & O & $\bullet$ & O \\
\hline Lecane elsa Hauer, 1931 & 0 & 0 & 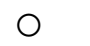 & O & $\mathrm{O}$ & 0 & 0 \\
\hline Lecane lamellata (Daday, 1893) & 0 & 0 & 0 & 0 & 0 & 0 & 0 \\
\hline Lecane luna (Müller, 1776) & 0 & 0 & 0 & 0 & 0 & 0 & 0 \\
\hline Lepadella patella (Müller, 1773) & 0 & 0 & $\bigcirc$ & O & 0 & $\mathrm{O}$ & O \\
\hline Lepadella patella persimilis De Ridder, 1961 & O & O & O & O & O & 0 & O \\
\hline Notholca salina Focke, 1961 & 0 & 0 & 0 & 0 & 0 & 0 & 0 \\
\hline Ostracoda (unidentified ostracods) & 1 & 1 & 1 & 1 & 1 & 1 & 1 \\
\hline Anostraca & 0 & 2 & 2 & 2 & 1 & 0 & 1 \\
\hline Artemia salina (Linnaeus, 1758) & 0 & 0 & 0 & 0 & 0 & O & 0 \\
\hline Phallocryptus spinosus (Milne-Edwards, 1840) & 0 & 0 & 0 & 0 & 0 & 0 & 0 \\
\hline Copepoda & 3 & 1 & 1 & 1 & 3 & 4 & 3 \\
\hline Arctodiaptomus salinus (Daday, 1885) & $\bullet$ & O & O & O & 0 & ○ & 0 \\
\hline Diacyclops bicuspidatus odessanus (Shmankevich, 1875) & 0 & 0 & 0 & 0 & 0 & 0 & 0 \\
\hline Metacyclops minutus minutus (Claus, 1863) & O & O & O & O & O & 0 & $\mathrm{O}$ \\
\hline Unidentified harpacticoids & 0 & 0 & 0 & ○ & 0 & 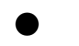 & 0 \\
\hline Unidentified cyclopoid & 0 & O & $\bigcirc$ & O & O & O & O \\
\hline Cladocera & 2 & 1 & 2 & 2 & 5 & 9 & 7 \\
\hline Alona intermedia Sars, 1862 & 0 & 0 & 0 & 0 & 0 & 0 & 0 \\
\hline Bosmina (Bosmina) longirostris (O.F. Müller, 1776) & 0 & 0 & 0 & 0 & 0 & 0 & 0 \\
\hline Chydorus ovalis Kurz, 1875 & 0 & 0 & 0 & 0 & 0 & 0 & 0 \\
\hline Ceriodaphnia reticulata (Jurine, 1820) & O & O & $\bigcirc$ & O & O & 0 & O \\
\hline Coronatella rectangula (Sars, 1862) & 0 & 0 & 0 & 0 & 0 & 0 & 0 \\
\hline Daphnia (Daphnia) cucullata Sars, 1862 & O & O & $\bigcirc$ & ○ & $\bullet$ & $\bullet$ & O \\
\hline Daphnia (Ctenodaphnia) magna Straus, 1820 & O & O & O & ○ & 0 & 0 & 0 \\
\hline Daphnia (Ctenodaphnia) mediterranea Alonso, 1985 & 0 & O & 0 & O & O & O & 0 \\
\hline Daphnia sp. O. F. Müller, 1785 & 0 & 0 & 0 & 0 & 0 & 0 & 0 \\
\hline
\end{tabular}


A. Karagianni et al.: Ann. Limnol. - Int. J. Lim. 2018, 54, 14

Table A1. (continued).

\begin{tabular}{|c|c|c|c|c|c|c|c|}
\hline & MLA & AER & SOR & ORP & AKR & PAR & ORO \\
\hline Moina brachiata (Jurine, 1820) & 0 & 0 & 0 & 0 & 0 & 0 & 0 \\
\hline Pleuroxus letourneuxi (Richard, 1888) & 0 & 0 & 0 & 0 & 0 & 0 & 0 \\
\hline
\end{tabular}

